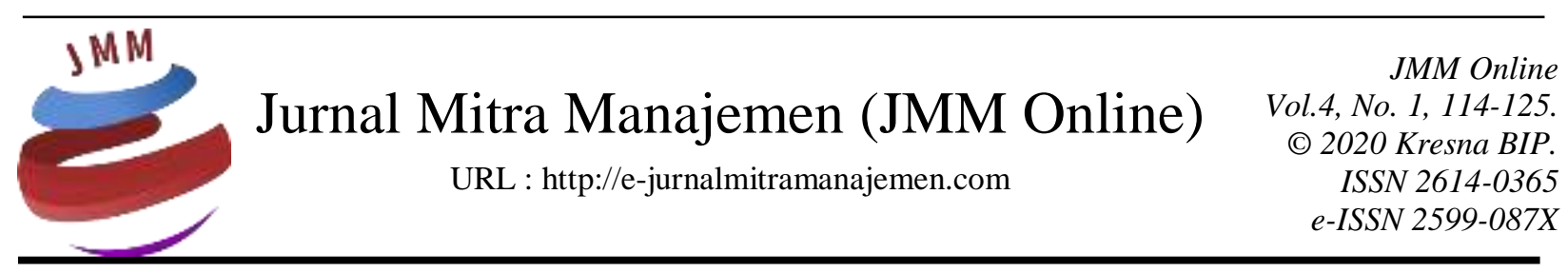

\title{
PENGARUH TINGKAT SUKU BUNGA DASAR KREDIT TERHADAP JUMLAH KREDIT PADA SEKTOR MIKRO (STUDI PADA BANK KONVENSIONAL DI INDONESIA PERIODE TAHUN 2014-2018)
}

\author{
Ravalia Putri Adela $^{1)}$, Astrie Krisnawati ${ }^{2)}$ \\ Universitas Telkom
}

INFORMASI ARTIKEL

Dikirim : 15 Januari 2020

Revisi pertama : 20 Januari 2020

Diterima : 23 Januari 2020

Tersedia online : 31 Januari 2020

Kata Kunci : SBDK Mikro, Kredit Mikro

Email : ravaliaputriadela@gmail.com ${ }^{1)}$, astriekrisnawati@telkomuniversity.ac.id ${ }^{2)}$

\section{ABSTRAK}

Bank berperan dalam menyediakan layanan kredit bagi masyrakat namun tingginya tingkat SBDK, khususnya untuk sektor mikro masih dianggap memberatkan debitur. Penelitian ini bertujuan untuk mengetahui pengaruh tingkat Suku Bunga Dasar Kredit (SBDK) mikro terhadap jumlah kredit yang disalurkan pada sektor mikro. Variabel independen yang digunakan adalah tingkat SBDK sektor mikro $(X)$ sedangkan variabel dependen adalah jumlah kredit yang disalurkan pada sektor mikro (Y). Populasi adalah bank-bank umum konvensional di Indonesia periode tahun 2014-2018. Pengambilan sampel menggunakan metode purposif dengan jumlah sampel sebanyak 25 bank konvensional. Teknik analisis yang digunakan adalah regresi data panel dengan model REM. Hasil penelitian menyimpulkan bahwa SBDK sektor mikro tidak berpengaruh signifikan terhadap jumlah kredit yang disalurkan pada sektor mikro periode tahun 2014-2018. 


\section{PENDAHULUAN \\ Latar Belakang}

Perbankan merupakan lembaga keuangan yang dapat mempengaruhi tingkat pertumbuhan ekonomi di suatu negara. Bank bertujuan untuk menghimpun dana dan menyalurkannya ke masyarakat serta menyediakan layanan atau jasa untuk memperlancar lalu lintas pembayaran. Menurut Undang-Undang Negara Republik Indonesia Nomor 10 tahun 1998 tentang perbankan, dijelaskan bahwa bank adalah badan usaha yang menghimpun dana dari masyarakat dalam bentuk simpanan dan menyalurkannya kepada masyarakat dalam bentuk kredit dan atau bentuk-bentuk lainnya dalam rangka meningkatkan taraf hidup rakyat banyak. Sebagai lembaga intermediasi, salah satu layanan keuangan dari perbankan yang disediakan bagi masyarakat adalah kredit.

Kredit merupakan penyediaan uang atau tagihan yang disamakan dengan uang berdasarkan kesepakatan pinjam meminjam yang mewajibkan peminjam untuk melunasinya dalam jangka waktu tertentu dengan pemberian bunga. Selain menguntungkan pihak bank melalui bunga kredit yang akan diterima dari nasabah, tujuan pemberian kredit adalah untuk memenuhi kebutuhan dana masyarakat baik untuk konsumsi, investasi, dan modal kerja. Namun, akses terhadap layanan keuangan khususnya kredit di Indonesia belum sepenuhnya terdistribusi secara merata ke setiap sektor perekonomian. Berdasarkan data Net Ekspansi Kredit Usaha Mikro, Kecil, dan Menengah (UMKM) Perbankan per Januari 2018 yang dipublikasikan oleh Bank Indonesia, jumlah kredit yang disalurkan dalam bentuk kredit UMKM hingga akhir Desember 2017 berjumlah Rp 89,987 triliun, atau hanya 13,93\% dari keseluruhan kredit yang disalurkan oleh perbankan. Dari angka tersebut, kredit yang disalurkan untuk sektor mikro memiliki persentase terkecil dimana 29,57\% disalurkan untuk kredit usaha mikro, 32,25\% disalurkan untuk kredit usaha kecil, dan $38.18 \%$ disalurkan untuk kredit usaha menengah (Bank Indonesia, 2018). Data tersebut dapat menginformasikan bahwa akses terhadap layanan kredit bagi masyarakat pemilik Usaha Mikro, Kecil dan Menengah (UMKM) masih rendah, terutama untuk kredit usaha mikro.

Hambatan pemberian kredit mikro dapat disebabkan oleh beberapa faktor, misalnya persyaratan dan administrasi pemberian kredit belum terpenuhi, resiko pemberian kredit pada usaha mikro dinilai masih terlalu besar, ataupun penetapan suku bunga kredit yang terlalu tinggi dan memberatkan nasabah peminjam atau debitur (Bank Indonesia, 2018). Penetapan suku bunga kredit yang akan dibebankan kepada nasabah setiap bank di Indonesia didasarkan pada tingkat Suku Bunga Dasar Kredit (SBDK). SBDK merupakan suku bunga terendah untuk menetapkan suku bunga kredit bank yang dihitung dengan mempertimbangkan beberapa aspek tertentu, seperti Harga Pokok Dana untuk Kredit (HPDK), profit margin, dan biaya overhead atau biaya yang harus dikeluarkan bank dalam kegiatan pemberian kredit. Biaya overhead sendiri dibagi lagi menjadi dua, yaitu biaya overhead dana dan biaya overhead kredit. Biaya overhead dana berkaitan dengan biaya yang dikeluarkan bank untuk melakukan ekspansi jaringan dengan membuka cabang bank maupun ATM di lokasi yang terpencil dan sulit dijangkau. Sedangkan biaya overhead kredit mencakup biaya penyaluran dan penagihan kredit yang besarnya tergantung pada segmen kreditnya. 
Secara umum, biaya overhead kredit untuk segmen korporasi berkisar $1 \%$ sementara untuk segmen mikro dapat mencapai lebih dari $10 \%$. Tingginya biaya overhead kredit untuk segmen mikro ini disebabkan oleh besarnya tenaga kerja yang dibutuhkan untuk penyaluran kredit dan penagihan yang harus lebih sering dilakukan, yaitu dalam hituan mingguan atau bulanan. Biaya ekspansi jaringan untuk segmen mikro juga lebih besar karena luasnya sebaran nasabah mikro. Hal ini mengakibatkan tingginya total biaya overhead untuk segmen mikro sehingga nilai Suku Bunga Dasar Kredit yang ditetapkan pun cenderung tinggi.

Dibandingkan dengan jenis kredit lainnya, kredit mikro memiliki Suku Bunga Dasar Kredit yang lebih tinggi. Pada bulan Desember 2017, tercatat bahwa tingkat SBDK tertinggi untuk kredit mikro adalah sebesar 31,45\% sedangkan SBDK tertinggi untuk kredit korporasi hanya sebesar 19,26\% dan kredit ritel sebesar 17,76\% (Otoritas Jasa Keuangan, 2019). Walaupun besaran kredit yang dipinjam oleh setiap nasabah kredit mikro relatif kecil dibandingkan kredit lainnya, usaha mikro dianggap sebagai usaha yang memiliki resiko yang cukup besar dan cenderung menghasilkan biaya overhead yang tinggi, seperti biaya tenaga kerja yang lebih tinggi untuk proses penyaluran dan penagihan kredit serta kebutuhan biaya ekspansi jaringan untuk kredit mikro karena luasnya persebaran nasabah mikro. Selain itu, penetapan suku bunga kredit yang tinggi dianggap seimbang dengan besarnya profit margin yang mampu dihasilkan oleh usaha mikro dalam aktivitas operasionalnya. Namun tingginya penetapan SBDK untuk kredit mikro masih dianggap cukup memberatkan, sehingga para pelaku usaha mikro akhirnya menolak untuk memanfaatkan layanan kredit perbankan.

Penelitian mengenai suku bunga kredit pernah dilakukan oleh Barus dan $\mathrm{Lu}$ (2013) yang meneliti pengaruh spread tingkat suku bunga terhadap jumlah kredit yang disalurkan pada sektor UMKM. Hasil penelitian menyimpulkan bahwa spread suku bunga berpengaruh negatif signifikan terhadap jumlah kredit yang disalurkan pada sektor UMKM. Penelitian lain mengenai faktor yang mempengaruhi jumlah kredit yang disalurkan juga pernah dilakukan oleh Effendi (2016), namun dengan variabel independen yang berbeda yaitu tingkat suku bunga kredit. Penelitian tersebut menyimpulkan bahwa tingkat suku bunga kredit memiliki pengaruh yang negatif dan signifikan terhadap kredit UMKM. Berdasarkan penelitian tersebut, penulis tertarik untuk menyempurnakan penelitian serupa dengan variabel independen lain dan tahun pengamatan data terbaru, yaitu menganalisis pengaruh Suku Bunga Dasar Kredit (SBDK) terhadap jumlah kredit yang disalurkan dengan menggunakan data tahun 2014-2018 serta difokuskan pada sektor usaha mikro.

\section{Rumusah Masalah}

Berdasarkan uraian diatas, rumusan masalah dalam penelitian ini adalah :

1. Bagaimana tingkat Suku Bunga Dasar Kredit untuk kredit mikro yang ditetapkan oleh bank umum di Indonesia periode tahun 2014-2018?

2. Bagaimana jumlah kredit yang disalurkan oleh bank umum di Indonesia pada sektor mikro periode tahun 2014-2018?

3. Bagaimana pengaruh tingkat Suku Bunga Dasar Kredit terhadap jumlah kredit yang disalurkan pada sektor mikro periode tahun 2014-2018? 


\section{Tujuan Penelitian}

Berdasarkan rumusan masalah diatas, tujuan dari penelitian ini adalah :

1. Untuk mengetahui tingkat Suku Bunga Dasar Kredit untuk kredit mikro yang ditetapkan oleh bank umum di Indonesia periode tahun 2014-2018.

2. Untuk mengetahui jumlah kredit yang disalurkan oleh bank umum di Indonesia pada sektor mikro periode tahun 2014-2018.

3. Untuk mengetahui pengaruh tingkat Suku Bunga Dasar Kredit terhadap jumlah kredit yang disalurkan pada sektor mikro periode tahun 2014-2018.

\section{KAJIAN PUSTAKA \\ Pengertian Bank}

Menurut Undang-Undang Republik Indonesia Nomor 10 tahun 1998 tentang perbankan, dijelaskan bahwa pengertian bank adalah badan usaha yang menghimpun dana dari masyarakat dalam bentuk simpanan dan menyalurkannya kepada masyarakat dalam bentuk kredit dan atau bentuk-bentuk lainnya dalam rangka meningkatkan taraf hidup rakyat banyak. Bank juga didefinisikan sebagai suatu lembaga yang bergerak dalam bidang keuangan yang kegiatan utamanya yaitu menerima simpanan giro, tabungan, dan deposito serta menjadi tempat untuk meminjam uang (kredit) bagi masyarakat yang membutuhkannya (Kasmir, 2017).

Secara garis besar, perbankan memiliki aktivitas penghimpunan dana (funding), penyaluran dana (lending), dan aktivitas pelayanan. Dalam penghimpunan dana, bank berkewajiban untuk memberikan balas jasa atau imbalan pada masyarakat penyimpan dana dalam bentuk bunga atau bagi hasil dengan besaran yang telah disepakati sebelumnya oleh kedua belah pihak. Dalam aktivitas penyaluran dana, pihak peminjam (debitur) akan dikenakan jasa pinjaman dalam bentuk bunga kredit dan biaya administrasi sesuai kesepakatan antara kedua belah pihak. Sedangkan aktivitas jasa atau pelayanan yang disediakan bank meliputi jasa pemindahan uang (transfer), jasa penagihan (inkaso), jasa kliring, jasa penjualan mata uang asing (valas), jasa safe deposit box, dll (Kasmir, 2017).

\section{Suku Bunga Dasar Kredit}

Bank Indonesia menyebutkan bahwa Suku Bunga Dasar Kredit (SBDK) merupakan suku bunga terendah untuk menetapkan suku bunga kredit bank yang dihitung dengan mempertimbangkan beberapa aspek, yaitu Harga Pokok Dana untuk Kredit (HPDK), biaya overhead atau biaya perusahaan yang tidak berkaitan langsung dengan aktivitas operasi dalam proses pemberian kredit, dan profit margin. Selanjutnya, penetapan suku bunga kredit yang akan dibebankan pada debitur dihitung dengan menjumlahkan SBDK dan besaran premi resiko sesuai kebijakan masingmasing bank. Dengan demikian, besaran suku bunga kredit yang dikenakan kepada pihak debitur belum tentu sama dengan tingkat SBDK (Otoritas Jasa Keuangan, 2019)].

Bank sentral mengeluarkan SE BI No.13/5/DNP tahun 2011 perihal publikasi Suku Bunga Dasar Kredit yang bertujuan untuk meningkatkan transparansi informasi, meningkatkan good governance dan mendorong persaingan sehat dalam industri perbankan. Surat edaran ini menginstruksikan setiap perbankan untuk melakukan 
publikasi informasi SBDK melalui papan pengumuman di setiap kantor bank, halaman utama website, serta pengumuman di surat kabar bersamaan dengan pengumuman Laporan Keuangan Publikasi Triwulanan.

\section{Usaha Mikro, Kecil, dan Menengah (UMKM)}

Undang-Undang nomor 20 tahun 2008 tentang Usaha Mikro, Kecil, dan Menengah menyebutkan bahwa usaha mikro adalah usaha usaha produktif milik perorangan dan/ atau badan usaha perorangan dengan kriteria memiliki kekayaan bersih paling banyak Rp 50.000.000,00 (lima puluh juta rupiah) tidak termasuk tanah dan bangunan tempat usaha atau memiliki hasil penjualan tahunan paling banyak Rp300.000.000,00 (tiga ratus juta rupiah).

Usaha kecil adalah usaha ekonomi produktif yang berdiri sendiri, yang dilakukan oleh perorangan atau badan usaha yang bukan merupakan anak perusahaan atau bukan cabang perusahaan yang dimiliki, dikuasai, atau menjadi bagian baik langsung maupun tidak langsung dari usaha menengah atau usaha besar dengan kriteria memiliki kekayaan bersih lebih dari Rp 50.000.000,00 (lima puluh juta rupiah) sampai dengan paling banyak Rp 500.000.000,00 (lima ratus juta rupiah) tidak termasuk tanah dan bangunan tempat usaha atau memiliki hasil penjualan tahunan lebih dari Rp300.000.000,00 (tiga ratus juta rupiah) sampai dengan paling banyak Rp2.500.000.000,00 (dua milyar lima ratus juta rupiah).

Sedangkan usaha menengah adalah usaha ekonomi produktif yang berdiri sendiri, yang dilakukan oleh perorangan atau badan usaha yang bukan merupakan anak perusahaan atau bukan cabang perusahaan yang dimiliki, dikuasai, atau menjadi bagian baik langsung maupun tidak langsung dengan Usaha Kecil atau usaha besar dengan kriteria memiliki kekayaan bersih lebih dari Rp 500.000.000,00 (lima ratus juta rupiah) sampai dengan paling banyak Rp 10.000.000.000,00 (sepuluh milyar rupiah) tidak termasuk tanah dan bangunan tempat usaha atau memiliki hasil penjualan tahunan lebih dari Rp 2.500.000.000,00 (dua milyar lima ratus juta rupiah) sampai dengan paling banyak Rp 50.000.000.000,00 (lima puluh milyar rupiah).

\section{Kerangka Pemikiran}

Berdasarkan penjelasan sebelumnya, gambaran kerangka pemikiran untuk penelitian ini adalah sebagai berikut :

\section{Gambar 1. Kerangka Pemikiran}

\begin{tabular}{|c|c|}
\hline $\begin{array}{llll}X: & \text { Suku } & \text { Bunga } & \text { Dasar } \\
\text { Kredit } & \text { (SBDK) } & \text { sektor } \\
\text { mikro } & & \end{array}$ & $\begin{aligned} \text { Y : } & \text { Jumlah kredit yang } \\
& \text { disalurkan pada sektor } \\
& \text { mikro }\end{aligned}$ \\
\hline
\end{tabular}

\section{Hipotesis Penelitian}

Hipotesis adalah pernyataan sementara yang akan didukung oleh data empiris dalam penelitian. Hipotesis merupakan jawaban sementara terhadap suatu masalah yang masih bersifat praduga sehingga harus dibuktikan kebenarannya (Indrawati, 
2015). Berdasarkan uraian kerangka pemikiran, dapat dirumuskan hipotesis penelitian sebagai berikut:

H1 : Tingkat Suku Bunga Dasar Kredit (SBDK) sektor mikro berpengaruh signifikan terhadap jumlah kredit yang disalurkan pada sektor mikro.

\section{METODE PENELITIAN}

\section{Jenis Penelitian}

Penelitian ini bersifat kausal karena bertujuan untuk mengetahui pengaruh atau hubungan antar dua variabel atau lebih. Berdasarkan metodenya, penelitian tergolong dalam penelitian kuantitatif karena menggunakan data-data berupa angka yang bersumber dari laporan keuangan masing-masing bank. Penelitian dilakukan dengan sampel sebanyak 25 bank konvensional di Indonesia dengan periode pengamatan selama 5 tahun, yaitu dari tahun 2014-2018. Berdasarkan hal tersebut, penelitian dapat dikategorikan sebagai penelitian dengan tipe data panel karena menggunakan data gabungan antara time series dan cross section.

\section{Tempat, Waktu, dan Subjek Penelitian}

Tempat penelitian ini adalah bank-bank di Indonesia yang tergolong kedalam bank umum konvensional. Penelitian ini menggunakan laporan tahunan masingmasing bank dengan waktu pengamatan pada tahun 2014-2018. Subjek penelitian yang digunakan adalah bank-bank umum konvensional di Indonesia periode tahun 20142018.

\section{Populasi dan Sampel}

Populasi yang digunakan adalah bank-bank umum konvensional di Indonesia yaitu sebanyak 102 bank (Otoritas Jasa Keuangan, 2018). Pengambilan sampel menggunakan metode purposive sampling, dimana sampel akan diambil ketika memenuhi syarat atau kriteria yang telah ditentukan. Kriteria yang digunakan dalam pengambilan sampel adalah konsisten dalam melakukan penetapan Suku Bunga Dasar Kredit (SBDK) sektor mikro dari tahun 2014-2018, mempublikasi laporan tahunan secara lengkap dari tahun 2014-2108, tidak melakukan merger dan akuisisi dengan bank lain selama tahun 2014-2018, serta memberikan informasi secara lengkap mengenai jumlah kredit yang disalurkan pada sektor mikro dari tahun 2014-2018. Penghitungan jumlah sampel berdasarkan kriteria tersebut dapat dilihat pada Tabel 1.

Tabel 1. Kriteria Pengambilan Sampel

\begin{tabular}{|l|l|l|}
\hline No & Kriteria & Jumlah \\
\hline 1. & Bank umum konvensional di Indonesia & 102 \\
\hline 2. & $\begin{array}{l}\text { Tidak konsisten menetapkan Suku Bunga Dasar Kredit (SBDK) sektor } \\
\text { mikro dari tahun 2014-2018 }\end{array}$ & $(45)$ \\
\hline 3. & Tidak lengkap dalam mempublikasi laporan keuangan tahun 2014-2018 & $(4)$ \\
\hline 4. & Melakukan merger dan akuisisi dengan bank lain & $(3)$ \\
\hline 5. & $\begin{array}{l}\text { Tidak lengkap dalam memberikan informasi mengenai jumlah kredit } \\
\text { yang disalurkan pada sektor mikro dari tahun 2014-2018 }\end{array}$ & $(25)$ \\
\hline & Jumlah sampel & $\mathbf{2 5}$ \\
\hline
\end{tabular}

Sumber: Data Primer, diolah (2019) 
Berdasarkan kriteria tersebut, sampel yang akan digunakan berjumlah 25 bank umum konvensional di Indonesia dengan daftar sampel seperti yang tertera pada Tabel 2.

Tabel 2. Daftar Bank yang Termasuk dalam Sampel Penelitian

\begin{tabular}{|l|l|l|l|}
\hline No. & Nama Bank & No. & Nama Bank \\
\hline 1. & Bank Agris & 14. & Bank Tabungan Pensiunan Nasional \\
\hline 2. & Bank Artha Graha Internasional & 15. & Bank Yudha Bakti \\
\hline 3. & Bank Fama Internasional & 16. & BPD Bali \\
\hline 4. & Bank Harda Internasional & 17. & BPD DKI \\
\hline 5. & Bank Index Selindo & 18. & BPD Jawa Barat dan Banten \\
\hline 6. & Bank Kesejahteraan Ekonomi & 19. & BPD Jawa Timur \\
\hline 7. & Bank Mayapada International & 20. & BPD Kalimantan Barat \\
\hline 8. & Bank Maybank Indonesia & 21. & BPD Kalimantan Tengah \\
\hline 9. & Bank Mayora & 22. & BPD Nusa Tenggara Timur \\
\hline 10. & Bank MNC Internasional & 23. & BPD Riau Kepri \\
\hline 11. & BPD Banten & 24. & BPD Sulawesi Utara dan Gorontalo \\
\hline 12. & Bank Rakyat Indonesia & 25. & BPD Sumatera Utara \\
\hline 13. & Bank Sahabat Sampoerna & & \\
\hline
\end{tabular}

Sumber: Data Primer, diolah (2019)

\section{Teknik Pengumpulan Data}

Penelitian ini menggunakan data bersifat sekunder dari 25 bank umum konvensional di Indonesia yang termasuk dalam sampel penelitian. Pengumpulan data untuk variabel tingkat Suku Bunga Dasar Kredit (SBDK) sektor mikro bersumber dari publikasi Otoritas Jasa Keuangan. Sedangkan pengumpulan data untuk variabel jumlah kredit yang disalurkan pada sektor mikro bersumber dari laporan tahunan (annual report) tahun 2014-2018 yang dipublikasi oleh masing-masing bank sampel melalui situs resmi bank tersebut.

\section{Teknik Analisis Data}

Teknik analisis data yang digunakan dalam penelitian ini adalah uji t (uji parsial), uji $\mathrm{F}$ (uji simultan), dan koefisien determinasi $\left(\mathrm{R}^{2}\right)$. Persamaan regresi data panel yang digunakan adalah sebagai berikut:

Keterangan:

$$
\mathrm{Y}=\alpha+\mathrm{b}_{1} \mathrm{X}_{1 \mathrm{it}}+\mathrm{b}_{2} \mathrm{X}_{2 \mathrm{it}}+\mathrm{e}
$$

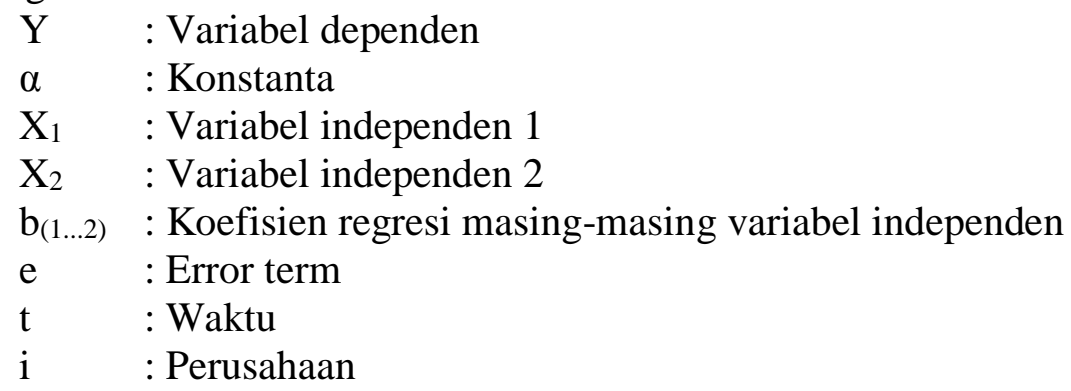




\section{HASIL PENELITIAN DAN PEMBAHASAN Statistik Deskriptif}

Penelitian menggunakan data yang bersumber dari 25 bank konvensional di Indonesia dengan periode pengamatan masing-masing sebanyak 5 tahun, yaitu dari tahun 2014-2018 sehingga jumlah observasi data adalah sebanyak 125 data. Statistika deskriptif bertujuan untuk memberikan gambaran dari hasil pengamatan terhadap data yang digunakan sehingga dapat memudahkan proses analisis serta dapat digunakan sebagai pengetahuan yang informatif bagi pihak dan peneliti lainnya. Hasil statistik deskriptif seperti yang terlihat pada Tabel 3 berguna untuk memberikan gambaran atau deskripsi suatu data yang dapat dilihat dari nilai rata-rata (mean), nilai tengah (median), nilai maksimum atau nilai tertinggi (maximum), nilai minimum atau nilai terendah (minimum), dan standar deviasi.

Tabel 3. Statistik Deskriptif

\begin{tabular}{|l|l|l|l|}
\hline No. & Statistik & $\mathbf{Y}$ & $\mathbf{X}$ \\
\hline 1. & Rata-rata & $8,21 \mathrm{E}+12$ & 15,14550 \\
\hline 2. & Nilai tengah & $3,00 \mathrm{E}+11$ & 14,83400 \\
\hline 3. & Nilai maksimum & $2,74 \mathrm{E}+14$ & 21,14800 \\
\hline 4. & Nilai minimum & $1,73 \mathrm{E}+08$ & 9,190000 \\
\hline 5. & Standar deviasi & $4,03 \mathrm{E}+13$ & 2,948836 \\
\hline
\end{tabular}

Sumber: Hasil Penelitian, diolah (2019)

Berdasarkan Tabel 3, dapat diketahui bahwa variabel Suku Bunga Dasar Kredit (SBDK) untuk kredit mikro yang ditetapkan oleh bank umum di Indonesia periode tahun 2014-2018 (X) memiliki nilai rata-rata sebesar 15,14550 dengan nilai tengah 14,83400 dan deviasi standar sebesar 2,948836. Nilai maksimum untuk variabel X dimiliki oleh PT BPD Jawa Barat dan Banten, Tbk. tahun 2015 dengan nilai sebesar 21,14800. Sedangkan nilai minimum untuk variabel X3 dimiliki oleh PT BPD Riau Kepri tahun 2017 dengan nilai sebesar 9,190000.

Variabel jumlah kredit yang disalurkan pada sektor mikro (Y) memiliki nilai rata-rata sebesar 8,21E+12 dengan nilai tengah 3,00E+11 dan standar deviasi sebesar 4,03E+13. Nilai variabel Y terbesar dimiliki oleh PT bank Rakyat Indonesia (Persero), Tbk pada tahun 2018 dengan nilai sebesar 2,74E+14. Sedangkan nilai variabel Y terkecil dimiliki oleh PT Bank Kesejahteraan Ekonomi tahun 2016 dengan nilai sebesar $1,73 \mathrm{E}+08$.

\section{Model Regresi Data Panel}

Dalam menentukan model regresi yang tepat, uji pertama yang dilakukan adalah uji Chow untuk memilih antara Common Effect Model (CEM) atau Fixed Effect Model (FEM) dengan kaidah pengambilan keputusan sebagai berikut:

Jika probabilitas > 0,05: H0 diterima, CEM lebih tepat untuk digunakan

Jika probabilitas < 0,05: H0 ditolak, FEM lebih tepat untuk digunakan

Tabel 4. Hasil Uji Chow

\begin{tabular}{|l|l|l|l|}
\hline Effects Test & Statistic & d.f. & Probabilitas \\
\hline Cross-section F & 13,352119 & $(24,99)$ & 0,0000 \\
\hline Cross-section Chi-square & 180,478317 & 24 & 0,0000 \\
\hline
\end{tabular}

Sumber: Hasil Penelitian, diolah (2019) 
Berdasarkan hasil perhitungan Uji Chow yang ditunjukkan pada Tabel 4, dapat diketahui bahwa nilai probabilitas adalah sebesar 0,0000 < 0,05 sehingga $\mathrm{H} 0$ ditolak dan $\mathrm{H} 1$ diterima, atau dapat disimpulkan bahwa penggunaan model FEM lebih tepat dibandingkan dengan model CEM. Selanjutnya FEM akan dibandingkan dengan Random Effect Model (REM) sehingga dilakukan Uji Hausman dengan kaidah pengambilan keputusan sebagai berikut :

Jika probabilitas > 0,05: H0 diterima, REM lebih tepat untuk digunakan

Jika probabilitas < 0,05: H0 ditolak, FEM lebih tepat untuk digunakan

\section{Tabel 5. Hasil Uji Hausman}

\begin{tabular}{|l|l|l|l|}
\hline Test Summary & Chi-Sq. Statistic & Chi-Sq. d.f. & Probabilitas \\
\hline Cross-section random & 2,469901 & 1 & 0,1160 \\
\hline
\end{tabular}

Sumber: Hasil Penelitian, diolah (2019)

Berdasarkan hasil perhitungan Uji Hausman yang ditunjukkan pada Tabel 5, dapat diketahui bahwa nilai probabilitas adalah sebesar 0,1160>0,05 sehingga dapat disimpulkan bahwa penggunaan model REM lebih tepat dibandingkan dengan model FEM. Dari kedua uji yang telah dilakukan, didapatkan keputusan bahwa model yang paling tepat untuk digunakan dalam penelitian ini adalah Random Effect Model (REM). Hasil regresi untuk model terpilih dapat dilihat pada Tabel 6.

Tabel 6. Hasil Regresi dengan Random Effect Model (REM)

\begin{tabular}{|c|c|c|c|c|c|}
\hline Variabel & Koefisien & Std. Error & t-Statistik & \multicolumn{2}{|c|}{ Probabilitas } \\
\hline $\mathrm{C}$ & $7,99 \mathrm{E}+12$ & $1,83 \mathrm{E}+13$ & 0,436884 & \multicolumn{2}{|c|}{0,6630} \\
\hline $\mathrm{X}$ & $1,46 \mathrm{E}+10$ & $1,12 \mathrm{E}+12$ & 0,013072 & \multicolumn{2}{|c|}{0,9896} \\
\hline \multicolumn{2}{|c|}{ R-squared } & 0,000010 & \multicolumn{2}{|c|}{ S.D. dependent var } & $2,15 \mathrm{E}+13$ \\
\hline \multicolumn{2}{|c|}{ Adjusted R-squared } & $-0,008129$ & \multicolumn{2}{|l|}{ F-Statistic } & 0,000169 \\
\hline \multicolumn{2}{|c|}{ S.E. of regression } & $2,16 \mathrm{E}+13$ & \multicolumn{2}{|c|}{ Prob (F-Statistic) } & 0,989653 \\
\hline \multicolumn{2}{|c|}{ Mean dependent var } & $2,24 \mathrm{E}+12$ & \\
\hline
\end{tabular}

Sumber: Hasil Penelitian, diolah (2019)

Random Effect Model termasuk dalam model regresi data panel dengan pendekatan Generalized Least Square (GLS), sehingga tidak perlu dilakukan uji asumsi klasik. Hal ini mengacu pada pendapat Basuki dan Prawoto (2016) yang mengemukakan bahwa uji asumsi klasik hanya perlu dilakukan pada model regresi dengan pendekatan Ordinary Least Square (OLS).

\section{Analisis Regresi Data Panel}

Hasil analisis regresi data panel dari data-data yang digunakan dalam penelitian ini dapat dilihat pada Tabel 7.

Tabel 7. Hasil Analisis Regresi Data Panel

\begin{tabular}{|l|l|l|l|l|}
\hline Variabel & Koefisien & Std. Error & t-Statistik & Probabilitas \\
\hline $\mathrm{C}$ & $7,99 \mathrm{E}+12$ & $1,83 \mathrm{E}+13$ & 0,436884 & 0,6630 \\
\hline $\mathrm{X}$ & $1,46 \mathrm{E}+10$ & $1,12 \mathrm{E}+12$ & 0,013072 & 0,9896 \\
\hline
\end{tabular}

Sumber: Hasil Penelitian, diolah (2019)

Berdasarkan hasil pada Tabel 7, didapatkan persamaan regresi linier sebagai berikut:

$$
\mathrm{Y}=7,99 \mathrm{E}+12+1,46 \mathrm{E}+10 \mathrm{X}
$$


Dapat diketahui bahwa nilai konstanta adalah sebesar 7,99E+12 artinya jika variabel tingkat Suku Bunga Kredit sektor mikro (X) bernilai 0, maka nilai jumlah kredit yang disalurkan pada sektor mikro (Y) adalah sebesar konstanta itu sendiri, yaitu sebesar 7,99E+12 satuan.

Nilai koefisien X sebesar 1,46E+10 artinya setiap penambahan 1 satuan pada variabel tingkat Suku Bunga Dasar Kredit sektor mikro (X) akan menyebabkan peningkatan pada variabel jumlah kredit yang disalurkan pada sektor mikro (Y) sebesar $1,46 \mathrm{E}+10$ satuan.

\section{Uji Hipotesis}

Uji hipotesis bertujuan untuk mengetahui pengaruh variabel independen terhadap variabel dependen yang digunakan dalam penelitian. Kaidah pengambilan keputusan dalam uji hipotesis adalah :

Jika nilai probabilitas > 0,05: H0 diterima, artinya variabel independen tidak berpengaruh signifikan terhadap variabel dependen.

Jika nilai probabilitas < 0,05: H0 ditolak, artinya variabel independen berpengaruh signifikan terhadap variabel dependen.

Adapun hasil uji hipotesis dapat dilihat dari nilai probabilitas variabel independen yang dihasilkan melalui regresi dengan model terpilih, yaitu Random Effect Model (REM). Berdasarkan nilai yang ditunjukkan pada Tabel 6, dapat dilihat bahwa nilai probabilitas variabel Suku Bunga Dasar Kredit (SBDK) sektor mikro adalah sebesar 0,9896>0,05 sehingga H0 diterima dan H1 ditolak, artinya dapat dikatakan bahwa variabel Suku Bunga Dasar Kredit (SBDK) untuk sektor mikro (X) tidak berpengaruh signifikan terhadap variabel jumlah kredit yang disalurkan pada sektor mikro (Y).

\section{Koefisien Determinasi $\left(\mathbf{R}^{2}\right)$}

Koefisien determinasi digunakan untuk mengukur kecocokan atau kesesuaian garis regresi dengan datanya. Dengan kata lain, koefisien determinasi dapat mengukur seberapa jauh atau seberapa besar kemampuan model regresi dalam menjelaskan variabel dependen. Hasil perhitungan Koefisien Determinasi dapat dilihat dari nilai RSquared yang dihasilkan melalui regresi dengan Random Effect Model (REM), seperti yang ditunjukkan pada Tabel 6. Dapat diketahui bahwa nilai R-Squared yang dihasilkan adalah sebesar 0,000010 atau dapat disimpulkan bahwa sebesar 0,0010\% jumlah kredit yang disalurkan pada sektor mikro dipengaruhi oleh variabel SBDK sektor mikro. Sedangkan sisanya, yaitu sebesar 99,999\% dijelaskan oleh variabelvariabel lain di luar model regresi.

\section{Analisis Pengaruh SBDK Sektor Mikro (X) terhadap Jumlah Kredit yang Disalurkan pada Sektor Mikro (Y)}

Dalam penelitian ini, variabel Suku Bunga Dasar Kredit (SBDK) sektor mikro digunakan untuk melengkapi hasil penelitian yang dilakukan oleh Effendi (2016) yang menganalisis pengaruh tingkat suku bunga kredit terhadap kredit UMKM. Hasil penelitian tersebut mengemukakan bahwa tingkat suku bunga kredit memiliki pengaruh yang negatif dan signifikan terhadap jumlah kredit mikro. Namun, nilai 
SBDK yang ditetapkan oleh perbankan tidak sama dengan nilai suku bunga kredit yang akan dibebankan pihak bank pada debiturnya. Tingkat suku bunga kredit merupakan penjumlahan dari nilai SBDK dengan nilai premi resiko kreditnya, dimana premi resiko bergantung pada potensi kerugian dan resiko dari sektor industri yang akan dibiayai serta resiko dari masing-masing calon debitur. Hasil penelitian ini menunjukkan bahwa variabel Suku Bunga Dasar Kredit (SBDK) sektor mikro secara parsial tidak berpengaruh signifikan terhadap variabel jumlah kredit yang disalurkan pada sektor mikro (Y). Hal ini dapat disebabkan karena SBDK belum memperhitungkan faktor premi resiko sebagai penentu akhir dalam penetapan tingkat suku bunga kredit yang dapat berpengaruh terhadap jumlah penyaluran kredit perbankan. Dengan kata lain, dapat disimpulkan bahwa tingkat SBDK sektor mikro tidak dapat mempengaruhi jumlah kredit yang disalurkan pada sektor mikro.

\section{KESIMPULAN DAN SARAN \\ Kesimpulan}

Berdasarkan hasil analisis dan pembahasan yang telah dijelaskan sebelumnya, kesimpulan dari penelitian ini adalah :

Variabel Suku Bunga Dasar Kredit untuk kredit mikro yang ditetapkan oleh bank umum di Indonesia periode tahun 2014-2018 (X) memiliki nilai rata-rata sebesar 15,14550 dengan nilai tengah sebesar 14,83400 dan deviasi standar sebesar 2,948836. Nilai maksimum untuk variabel X dimiliki oleh PT BPD Jawa Barat dan Banten, Tbk. tahun 2015 dengan nilai sebesar 21,14800. Sedangkan nilai minimum untuk variabel X dimiliki oleh PT BPD Riau Kepri tahun 2017 dengan nilai sebesar 9,190000.

Variabel jumlah kredit yang disalurkan pada sektor mikro (Y) memiliki nilai rata-rata sebesar 8,21E+12 dengan nilai tengah 3,00E+11 dan standar deviasi sebesar 4,03E+13. Nilai variabel Y terbesar dimiliki oleh PT bank Rakyat Indonesia (Persero), Tbk pada tahun 2018 dengan nilai sebesar 2,74E+14. Sedangkan nilai variabel Y terkecil dimiliki oleh PT Bank Kesejahteraan Ekonomi tahun 2016 dengan nilai sebesar 1,73E+08.

Suku Bunga Dasar Kredit (SBDK) sektor mikro tidak berpengaruh signifikan terhadap jumlah kredit yang disalurkan pada sektor mikro periode tahun 2014-2018.

\section{Saran} adalah:

Berdasarkan penelitian yang telah dilakukan, saran yang dapat diberikan a. Saran Teoritis

Bagi peneliti selanjutnya diharapkan dapat melakukan penelitian serupa dengan tahun pengamatan terbaru serta mengembangkan variabel pengamatan yang lain. Sebagai contoh adalah pengamatan terhadap variabel premi resiko kredit yang merupakan faktor penentu lain selain SBDK dalam penetapan tingkat suku bunga kredit.

Penelitian ini hanya berfokus pada sektor usaha mikro sehingga penelitian selanjutnya dapat dilakukan dengan objek pengamatan yang lain, seperti sektor usaha kecil, sektor usaha menengah, atau sektor UMKM secara keseluruhan. Hasil 
penelitian ini dapat dijadikan sebagai referensi pembanding untuk penelitian selanjutnya.

b. Saran Praktis

Pemerintah dan berbagai pihak terkait dapat meningkatkan literasi keuangan dengan memberikan lebih banyak pengetahuan mengenai perbankan dan layanannya kepada masyarakat, sehingga dapat mendorong masyarakat untuk lebih optimal dalam memanfaatkan layanan keuangan formal.

Pemerintah dan berbagai pihak terkait dapat mengawasi penetapan tingkat Suku Bunga Dasar Kredit (SBDK) khususnya SBDK sektor mikro yang menjadi dasar penetapan suku bunga kredit yang akan dibebankan pada pihak debitur. Hal ini bertujuan untuk dapat menetapkan tingkat bunga kredit yang rasional dan tidak dianggap terlalu memberatkan sehingga para pelaku usaha sektor mikro dapat mengoptimalkan pemanfaatan layanan keuangan yang disediakan perbankan.

\section{DAFTAR PUSTAKA}

Bank Indonesia. 2018. Net Ekspansi Kredit Usaha Mikro, Kecil, dan Menengah (UMKM) Perbankan. Bank Indonesia.

Barus, Andreani C., dan Lu, Marya. 2013. Pengaruh Tingkat Suku Bunga dan Rasio Keuangan terhadap Penyaluran Kredit UMKM pada Bank Umum di Indonesia. Jurnal Wira Ekonomi Mikroskill, 3(1), 11-20.

Basuki, Agus T., dan Prawoto, Nano. 2016. Analisis Regresi dalam Penelitian Ekonomi dan Bisnis: Dilengkapi Aplikasi SPSS dan EViews. Depok: PT Rajagrafindo Persada.

Effendi, Ismain. 2016. Analisis Pengaruh Suku Bunga terhadap Kredit Usaha Mikro Kecil dan Menengah (UMKM) pada Bank Pembangunan Daerah (BPD) di Provinsi Jambi. Jurnal Ilmiah Universitas Batanghari Jambi, 16(1), 49-54.

Kasmir, Dr. 2017. Bank dan Lembaga Keuangan Lainnya Edisi Revisi 2014. Jakarta: Rajawali Pers.

Kunt, Asli D., Klapper, L., Singer, D., Ansar, S., dan Hess, J. 2018. The Global Findex Database 2017 Measuring Financial Inclusion and the Fintech Revolution. Washington, DC: World Bank Group.

Otoritas Jasa Keuangan. 2018. Direktori Perbankan Indonesia 2018. Otoritas Jasa Keuangan.

Otoritas Jasa Keuangan. 2019. Suku Bunga Dasar Kredit. Otoritas Jasa Keuangan. 